\title{
Phase Equilibrium Relations in the Binary System Bismuth Sesquioxide-Niobium Pentoxide
}

\author{
R.'S. Roth and J. L. Waring
}

(August 2, 1962)

\begin{abstract}
The phase equilibrium diagram for the binary system bismuth sesquioxide-niobiuni pentoxide has been constructed from observations of fusion characteristics and X-ray diffraction data. In the system five binary compounds were observed with $\mathrm{Bi}_{2} \mathrm{O}_{3}: \mathrm{Nb}_{2} \mathrm{O}_{5}$ ratios of $5: 3,1: 1,4: 9,1: 5$, and $1: 6$. The $1: 1$ compound was found to transform irreversibly (in laboratory time) from the orthorhombic bismutotantalite type structure to a triclinic form at about $1,020^{\circ} \mathrm{C}$ and melt congruently at $1,245^{\circ} \mathrm{C}$. The $5: 3$ compound melts incongruently at $1,193{ }^{\circ} \mathrm{C}$ the $4: 9$ at $1,183{ }^{\circ} \mathrm{C}$ and the $1: 6$ at $1,242{ }^{\circ} \mathrm{C}$. The $1: 5$ compound has a maximum temperature of stability at $1,095^{\circ} \mathrm{C}$ and the $4: 9$ and $1: 6$ compounds have minimum temperatures of stability at $1,070^{\circ} \mathrm{C}$ and $1,002{ }^{\circ} \mathrm{C}$ respectively. $\quad \mathrm{Nb}_{2} \mathrm{O}_{5}$ was found to enter into solid solution in $\mathrm{Bi}_{2} \mathrm{O}_{3}$, up to about 23.5 mole percent $\mathrm{Nb}_{2} \mathrm{O}_{5}$. The melting point is increased and the monoclinic-cubic phase transformation temperature is decreased. A morphotropic phase change occurrs at about 19.5 mole percent $\mathrm{Nb}_{2} \mathrm{O}_{5}$ from the cubic to a pseudocubic structure.
\end{abstract}

\section{Introduction}

A study of phase relationships in the binary system $\mathrm{Bi}_{2} \mathrm{O}_{3}-\mathrm{Nb}_{2} \mathrm{O}_{5}$ has been conducted as part of a program of fundamental phase equilibria studies of ceramic materials. Attempts to synthesize an orthorhombic $\mathrm{BiNbO}_{4}$ compound isostructural with the mineral bismutotantalite have been reported as failures by several workers [1, 2]. ${ }^{1}$ Aurivillius [2] has indicated that the resultant material was triclinic. No systematic attempt to study the phase equilibrium relations in the entire binary system has been previously published.

X-ray diffraction data, together with the melting points of the compounds and the solidus and liquidus temperatures at various compositions across the system have been obtained in order to construct an equilibrium diagram.

\section{Sample Preparation and Test Methods}

The following starting materials were employed for the preparation of specimens:

$\mathrm{Nb}_{2} \mathrm{O}_{5}$-high-purity grade niobium pentoxide. Spectrographic analysis indicated less than about 0.01 percent $\mathrm{Si}, 0.001$ percent $\mathrm{Ca}$ and $\mathrm{Mg}$, with $\mathrm{As}$, $\mathrm{Cu}$, and Ta only questionably present.

$\mathrm{Bi}_{2} \mathrm{O}_{3}$ - Reagent grade bismuth sesquioxide. Spectrographic analysis indicated less than about 0.01 percent $\mathrm{Fe}$ and $\mathrm{Si}, 0.001$ percent $\mathrm{Al}$ and $\mathrm{Pb}$, and 0.0001 percent $\mathrm{Ag}, \mathrm{Ca}, \mathrm{Cr}, \mathrm{Cu}, \mathrm{Mg}$, and $\mathrm{Mn}$, with Co questionably present.

For the preparation of the specimens the weight percentages were calculated to within \pm 0.01 percent, with no corrections made for percentage purity of

\footnotetext{
${ }^{1}$ Figures in brackets indicate the literature references at the end of this paper.
}

the raw materials except for loss on ignition. The starting materials were weighed to the nearest $\pm 0.1 \mathrm{mg}$, in sufficient quantities to yield $3 \mathrm{~g}$ batches. For most compositions each batch was mixed in a mechanical shaker for about $15 \mathrm{~min}$ and pressed into a disk in a $5 / 8$ in. diam mold at $10,000 \mathrm{lb} / \mathrm{in}^{2}{ }^{2}$ The disks were sandwiched between $\mathrm{Pt}$ foil disks, stacked in a $\mathrm{MgO}$ crucible and calcined in air to $700{ }^{\circ} \mathrm{C}$ for either 3 or $6 \mathrm{hr}$ in an electrically heated furnace. Some compositions were prepared by grinding a slurry of the weighed mixture and alcohol with an agate mortar and pestle for a few minutes. The slurry was then allowed to dry in air or dried under an infrared lamp, or in a drying oven, then pressed into a pellet and fired in the usual manner.

Following the preliminary heat treatment the disks were ground in an agate mortar, remixed, and a portion of the specimen reformed in a $5 / 8$ in. mold at $10,000 \mathrm{lb} / \mathrm{in}^{2}{ }^{2}$ and reheated to a desired temperature.

Subsolidus as well as melting point data were obtained by the quenching technique on samples sealed in platinum tubes. An electrically heated vertical tube furnace wound with 80 percent $\mathrm{Pt}-20$ percent $\mathrm{Rh}$ wire was used for the quenching experiments. The furnace was controlled by an a-c Wheatstone bridge controller which was capable of holding the temperature to at least $\pm 2{ }^{\circ} \mathrm{C}$ for an extended period of time. Temperatures were measured with a $\mathrm{Pt}$ versus $\mathrm{Pt} 10$ percent Rh thermocouple which had been calibrated against the melting points of $\mathrm{NaCl}\left(800.4{ }^{\circ} \mathrm{C}[3]\right)$ and $\mathrm{Au}\left(1,063{ }^{\circ} \mathrm{C}[4]\right)$. The thermocouple was recalibrated several times during the course of the work. When the tubes were opened the specimens were examined for physical appearances of melting. Specimens were 
suspended in the furnace by fine Pt wire. In order to quench, the wire was burned off, allowing the sealed tubes to drop out of the heating chamber into a beaker of water. The first sign of glazing of the surface of the specimen was interpreted as the first experimental evidence for the solidus temperature. Acceptance of this appearance as evidence of melting was found justified in many specimens by an abrupt difference in the X-ray diffraction patterns of the specimens. The tormation of a concave meniscus, without the formation of relatively large crystals, indicated the liquidus temperature. The precision of the temperature measurements for the experimental data points is about $\pm 2{ }^{\circ} \mathrm{C}$ and the overall accuracy of the reported temperatures is probably about $\pm 5^{\circ} \mathrm{C}$.

Equilibrium was considered to have been obtained when the X-ray diffraction patterns of specimens successively heated for longer times and/or at higher temperatures showed no change. X-ray diffraction powder patterns were made using a high angle recording Geiger counter diffractometer and nickel-filtered copper radiation, with the Geiger counter traversing the specimen at $1 / 4{ }^{\circ} 2 \theta / \mathrm{min}$ and the radiation being recorded on the chart at $1^{\circ} 2 \theta /$ in. The unit cell dimensions reported can be considered accurate to about \pm 2 in the last decimal place listed.

\section{Compounds in the $\mathrm{Bi}_{2} \mathrm{O}_{3}-\mathrm{Nb}_{2} \mathrm{O}_{5}$ System 3.1. $\mathrm{Bi}_{2} \mathrm{O}_{3}$}

Four polymorphs of $\mathrm{Bi}_{2} \mathrm{O}_{3}$ have been reported. The equilibrium and stability relations have been somewhat confused mainly because $\mathrm{Bi}_{2} \mathrm{O}_{3}$ reacts with almost any container, and also because the hightemperature forms are difficult or impossible to quench.

\section{a. Low-Temperature Monoclinic Modification}

It has been recognized by several workers $[5,6,7,8]$ that the monoclinic form is the true low-temperature stable modification. The structure of this phase has been described by Sillen $[6,9]$ who has shown by single crystal studies that, although the powder pattern can be indexed on the basis of orthorhombic symmetry, the true symmetry is monoclinic. The indexed X-ray diffraction powder pattern has been given by Sillen [6] and by Swanson et al. [10].

\section{b. High-Temperature Cubic Modification}

The monoclinic form of $\mathrm{Bi}_{2} \mathrm{O}_{3}$ transforms reversibly to a high-temperature form above $700{ }^{\circ} \mathrm{C}$. This transformation was first reported by Guertler [5] to be at $704{ }^{\circ} \mathrm{C}$ using D'TA apparatus, but since the composition of the container was not stated the results of this work were questioned by Schumb and Rittner [7]. Apparently only $\mathrm{Pt}$ can be used as a container for $\mathrm{Bi}_{2} \mathrm{O}_{3}$ at any appreciable temperature without fear of considerable contamination. Schumb and Rittner [7], using Pt containers found a temperature of $710^{\circ} \mathrm{C}$ as the transformation point. However, they postulated that the high-temperature form was tetragonal.
DTA and high-temperature X-ray data (to be reported in more detail in a future publication) have shown that the $\mathrm{Bi}_{2} \mathrm{O}_{3}$ used in this study transforms from monoclinic to cubic at $730 \pm 5{ }^{\circ} \mathrm{C}$, this phase remaining stable to the melting point at $825 \pm 5^{\circ} \mathrm{C}$. However, on cooling the cubic form of $\mathrm{Bi}_{2} \mathrm{O}_{3}$, it was observed that the monoclinic phase did not reform at $730{ }^{\circ} \mathrm{C}$. Instead, the cubic phase supercooled to about $650{ }^{\circ} \mathrm{C}$, then transformed to a tetragonal phase before reverting again to the monoclinic form at about $450{ }^{\circ} \mathrm{C}$.

The cubic form has an X-ray diffraction powder pattern resembling that of a face-centered cubic cell of about $5.5 \mathrm{~A}$. However Sillen [6] has pointed out that it is probably simple cubic with ordered oxygen vacancy positions somewhat similar to the cubic forms of $\mathrm{Sb}_{2} \mathrm{O}_{3}$ and $\mathrm{As}_{2} \mathrm{O}_{3}$.

\section{c. Metastable Tetragonal Modification}

A tetragonal form, structurally related to the cubic modification, was first reported by Sillen [6] who prepared it by very fast cooling of $\mathrm{Bi}_{2} \mathrm{O}_{3}$ vapor. It was also prepared by Schumb and Rittner [7] by a different method of condensation of a vapor. Both workers used a graphite furnace. The tetragonal form could not be obtained in this laboratory by condensing $\mathrm{Bi}_{2} \mathrm{O}_{3}$ vapors from a $\mathrm{Pt}$ dish of molten $\mathrm{Bi}_{2} \mathrm{O}_{3}$ onto a glass slide. It is still not known whether the graphite is necessary for obtaining the tetragonal form at room temperature. DTA and high-temperature X-ray patterns made in this laboratory on pure $\mathrm{Bi}_{2} \mathrm{O}_{3}$ indicate that under the conditions of the experiments the tetragonal form only occurs on cooling of the cubic form. It is found only in the range of 650 to $450{ }^{\circ} \mathrm{C}$ where the monoclinic form is the stable phase.

Sillen [6] reported the unit cell dimension of the tetragonal phase to be $a=10.93 \mathrm{~A}, c=5.62 \mathrm{~A}$, and Schumb and Rittner [7] obtained $a=10.93 \mathrm{~A}, c=$ $5.63 \mathrm{~A}$. In the present study the tetragonal form was obtained at room temperature by quenching, from $773^{\circ} \mathrm{C}$, a mixture of 99 mole percent $\mathrm{Bi}_{2} \mathrm{O}_{3}$ and 1 mole percent $\mathrm{Nb}_{2} \mathrm{O}_{5}$. The unit cell dimensions of this phase are $a=10.938 \mathrm{~A}, c=5.632 \mathrm{~A}$.

\section{d. Metastable Body-Centered Cubic Phase(s)}

Sillen [6] first reported the occurrence of a bodycentered cubic phase $(a=10.08 \mathrm{~A})$, which he found by fusing $\mathrm{Bi}_{2} \mathrm{O}_{3}$ in a porcelain crucible. He recognized that this phase was probably impure, and considered it to be a compound of $\mathrm{Bi}_{2} \mathrm{O}_{3}$ and a second metal oxide in the proportion of about $12 \mathrm{Bi}^{+3}$ ions to one other metal cation. Schumb and Rittner [7] were able to prepare a body-centered cubic phase $(a=10.245 \mathrm{~A})$ which they considered to be a metastable form of pure $\mathrm{Bi}_{2} \mathrm{O}_{3}(z=13)$ different from Sillen's phase. However, this phase could only be made by moderately fast cooling of the previously formed tetragonal phase. It should be pointed out here that even this "pure bismuth oxide" bodycentered cubic phase may well have had some carbon atoms present in the lattice, since the 
original tetragonal material had been prepared in a graphite crucible. In this laboratory a bodycentered cubic phase has been found to occur in a large number of binary systems containing $\mathrm{Bi}_{2} \mathrm{O}_{3}$. The thermal stability of the phases found in these systems will be discussed in a future publication.

\subsection{Compound $5 \mathrm{Bi}_{2} \mathrm{O}_{3} \cdot 3 \mathrm{Nb}_{2} \mathrm{O}_{5}$}

A compound was found in the present study at a ratio of $5 \mathrm{Bi}_{2} \mathrm{O}_{3} \cdot 3 \mathrm{Nb}_{2} \mathrm{O}_{5}$. The X-ray diffraction powder pattern listed in table 1 can be partially indexed on the basis of a tetragonally distorted pyrochlore type structure with a $c / a$ ratio less than one. The pseudotetragonal parameters are $a=10.912 \mathrm{~A}, c=$ $10.496 \mathrm{~A}$. If the $c$ axis is doubled $(20.992 \mathrm{~A})$ then the relatively strong peak at $6.99 \mathrm{~A}$ can be indexed as (003). However, this larger value does not account for all the extra peaks and the true symmetry is probably less than tetragonal. It should be noted that the powder pattern is always of quite poor quality regardless of the temperature from which the specimen is quenched or the length of time at which the specimen is held at temperature. This phenomenon is often indicative of a nonquenchable phase transformation and may indicate that the compound is actually tetragonal somewhat above room temperature.

The X-ray diffraction powder pattern of the compound $5 \mathrm{Bi}_{2} \mathrm{O}_{3} \cdot 3 \mathrm{Nb}_{2} \mathrm{O}_{5}$ is similar to that of the pseudotetragonally distorted pyrochlore previously found for $3 \mathrm{PbO} \cdot \mathrm{Nb}_{2} \mathrm{O}_{5}$ [11]. However, in the latter compound the $c / a$ ratio is greater than one instead of less than one. Another example of a tetragonally distorted pyrochlore with $c / a$ less than one was found by C. R. Robbins of this laboratory, in a specimen of $2 \mathrm{Bi}_{2} \mathrm{O}_{3}: \mathrm{GeO}_{2}$ quenched from the liquid.

TABLE 1. X-Ray diffraction powder data for the compound $5 \mathrm{Bi}_{2} \mathrm{O}_{3} \cdot 3 \mathrm{Nb}_{2} \mathrm{O}_{5}$ (CuK $\alpha$ radiation $)$

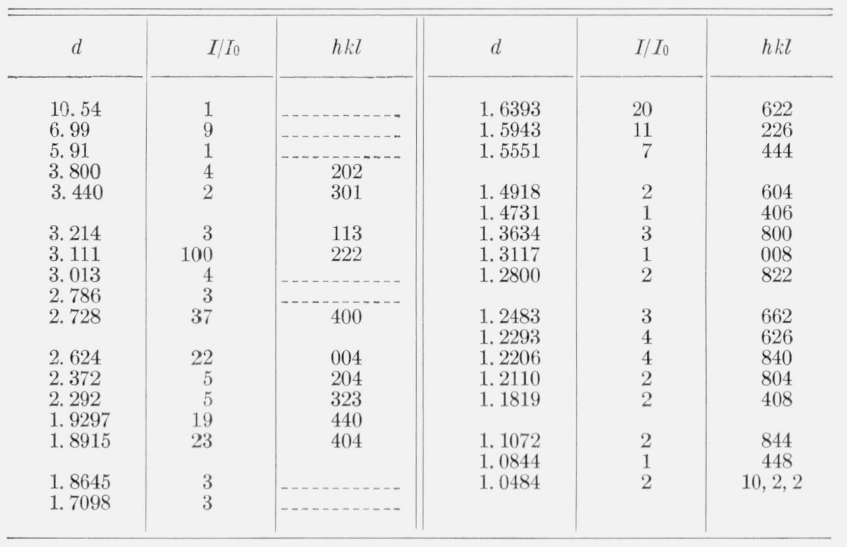

\subsection{Compound $\mathrm{Bi}_{2} \mathrm{O}_{3} \cdot \mathrm{Nb}_{2} \mathrm{O}_{5}$}

Although this composition has not been found in nature, the analogous composition $\mathrm{Bi}_{2} \mathrm{O}_{3} \cdot \mathrm{Ta}_{2} \mathrm{O}_{5}$ has been found and is called bismutotantalite. Both Dihlstrom [1] and Aurivillius [2] attempted to synthesize $\mathrm{BiNbO}_{4}$ and $\mathrm{BiTaO}_{4}$ but found that the synthetic compounds were different from the naturally occurring bismutotantalite, which is orthorhombic [12] and apparently isostructural with stibiotantalite $\left(\mathrm{SbTaO}_{4}\right)$ and antimony tetroxide $\left(\mathrm{Sb}_{2} \mathrm{O}_{4}\right)$ [Dihlstrom, 1].

\section{a. Low-Temperature Orthorhombic Modification}

The low-temperature orthorhombic modification, was found in all solid-state preparations of the $1: 1$ composition heated below about $1,020{ }^{\circ} \mathrm{C}$. How ever, once the high-temperature modification was formed the transformation could not be reversed by heating at lower temperatures. The X-ray diffraction powder pattern of the low-temperature modification is given in table 2 , indexed on the basis of an orthorhombic unit cell with $a=4.980 \mathrm{~A}, b=11.70 \mathrm{~A}$, and $c=5.675 \mathrm{~A}$.

TABLE 2. X-Ray diffraction powder data for the low temperature orthorhombic form of $\mathrm{Bi}_{2} \mathrm{O}_{3} \cdot \mathrm{Nb}_{2} \mathrm{O}_{5}$ (CuK $\alpha$ radiation)

\begin{tabular}{|c|c|c|c|c|c|}
\hline$d$ & $I / I_{0}$ & $h k l$ & $d$ & $I / I_{0}$ & $h k l$ \\
\hline 5.84 & 12 & 020 & 1. 6969 & 3 & 152 \\
\hline $\begin{array}{l}\text { J. } 54 \\
\text { 4. } 576\end{array}$ & 8 & $\begin{array}{l}020 \\
110\end{array}$ & $\begin{array}{l}1.0909 \\
1.6934\end{array}$ & $\begin{array}{r}3 \\
16\end{array}$ & $\begin{array}{l}102 \\
123\end{array}$ \\
\hline 3. 740 & 20 & 101 & 1. 6879 & 9 & 232 \\
\hline $\begin{array}{l}3.564 \\
3.153\end{array}$ & $\begin{array}{r}15 \\
100\end{array}$ & 111 & 16439 & 3 & \\
\hline & & & $\begin{array}{l}1.0459 \\
1.6337\end{array}$ & $\begin{array}{l}3 \\
4\end{array}$ & $\begin{array}{l}310 \\
251\end{array}$ \\
\hline 3. 071 & 8 & 130 & 1. 6106 & 5 & 133 \\
\hline 2. 924 & 40 & 040 & 1. 6080 & 7 & 062 \\
\hline $\begin{array}{l}2.838 \\
2.758\end{array}$ & $\begin{array}{r}26 \\
7\end{array}$ & $\begin{array}{l}002 \\
012\end{array}$ & 1. 5933 & 2 & 301 \\
\hline 2. 700 & 3 & 131 & 1. 5772 & 14 & 242 \\
\hline 2. 553 & 21 & 022 & $\begin{array}{l}1.5377 \\
1.5278\end{array}$ & $\begin{array}{r}20 \\
3\end{array}$ & $\begin{array}{l}321 \\
330\end{array}$ \\
\hline 2. 490 & $\begin{array}{l}21 \\
22\end{array}$ & 200 & 1. 5140 & 11 & 143 \\
\hline 2. 412 & 2 & 112 & $\begin{array}{l}1.4942 \\
1.40\end{array}$ & 2 & 213 \\
\hline 2. 305 & 20 & 141 & & & \\
\hline 2.294 & 8 & 032 & $\begin{array}{l}\text { 1. } 4635 \\
1.4621\end{array}$ & $\begin{array}{l}6 \\
4\end{array}$ & $\begin{array}{l}080 \\
252\end{array}$ \\
\hline 2. 292 & 10 & 220 & 1. 4411 & 2 & 072 \\
\hline 2. 272 & 3 & 122 & 1. 4228 & 3 & 312 \\
\hline 2. 238 & 6 & 211 & 1. 4190 & 2 & 004 \\
\hline $\begin{array}{l}2.125 \\
2.085\end{array}$ & $\begin{array}{l}1 \\
3\end{array}$ & $\begin{array}{l}221 \\
132\end{array}$ & 1. 4120 & 2 & 153 \\
\hline & & & 1. 4089 & 2 & 014 \\
\hline 2. 037 & 24 & 042 & 1.4063 & 2 & 233 \\
\hline 1. 9852 & 3 & 151 & 1. 4003 & 2 & 341 \\
\hline 1. 9689 & 6 & 231 & 1.3799 & 8 & 024 \\
\hline 1. 9485 & 2 & 060 & & & \\
\hline 1. 8967 & 27 & 240 & $\begin{array}{l}\text { 1. } 3636 \\
\text { 1. } 3564\end{array}$ & $\begin{array}{l}3 \\
1\end{array}$ & $\begin{array}{c}104 / 181 \\
114\end{array}$ \\
\hline 1. 8721 & 17 & 202 & 1. 3547 & 2 & 350 \\
\hline 1. 8486 & 8 & 212 & 1. 3513 & 5 & 262 \\
\hline 1. 8070 & 3 & 052 & 1. 3479 & 3 & 271 \\
\hline $\begin{array}{l}\text { 1. } 7800 \\
1.7694\end{array}$ & $\begin{array}{l}13 \\
14\end{array}$ & $\begin{array}{l}222 \\
103\end{array}$ & 1. 3333 & 2 & 034 \\
\hline & & 113 & 1. 3126 & 4 & 163 \\
\hline 1. 7302 & 34 & 161 & 1.5011 & & 082 \\
\hline
\end{tabular}

b. High-Temperature Triclinic Modification

From about $1,020{ }^{\circ} \mathrm{C}$ to the melting point, about $1,245{ }^{\circ} \mathrm{C}$, the stable modification of $\mathrm{Bi}_{2} \mathrm{O}_{3} \cdot \mathrm{Nb}_{2} \mathrm{O}_{5}$ is the triclinic form reported by Aurivillius [2]. The X-ray diffraction powder pattern, listed in table 3, was indexed on the basis of a triclinic unit cell with $a=7.61_{1} \mathrm{~A}, \quad b=5.53_{6} \mathrm{~A}, \quad c=7.91_{9} \mathrm{~A}, \quad \alpha=89.88^{\circ}, \quad \beta=$ $77.43^{\circ}, \gamma=87.15^{\circ}$ as compared with the rather inaccurate values calculated by Aurivillius [2] from Weissenburg photographs of $a=7.7_{1} \mathrm{~A}, \quad b=5.5_{5} \mathrm{~A}$, $c=7.9_{7} \mathrm{~A}, \alpha=89^{\circ}, \beta=77^{\circ}, \gamma=87^{\circ}$. 
TавцE 3. X-ray diffraction power data for the high temperature triclinic form of $\mathrm{Bi}_{2} \mathrm{O}_{3} \cdot \mathrm{Nb}_{2} \mathrm{O}_{5}$ (CuK $\alpha$ radiation $)$

\begin{tabular}{|c|c|c|c|c|c|}
\hline$d$ & $I / I_{0}$ & $h k l^{2}$ & $d$ & $I / I_{\mathrm{o}}$ & $h k l^{\mathrm{a}}$ \\
\hline $\begin{array}{l}7.41 \\
6.09\end{array}$ & $\begin{array}{c}21 \\
2\end{array}$ & $\begin{array}{l}100 \\
101\end{array}$ & $\begin{array}{l}2.219 \\
2.177\end{array}=$ & $\begin{array}{l}72 \\
4\end{array}$ & \\
\hline 4. 544 & 8 & 1110 & & & \\
\hline $\begin{array}{l}\text { 4. } 324 \\
3.867\end{array}$ & 3 & 110 & 2. 166 & 6 & \\
\hline 3. 867 & 14 & 002 & 2. 115 & 15 & \\
\hline $\begin{array}{l}\text { 3. } 779 \\
3\end{array}$ & 4 & $10 \overline{2}$ & 2.048 & 4 & \\
\hline $\begin{array}{l}3.710 \\
3.666\end{array}$ & $\begin{array}{r}15 \\
2\end{array}$ & $\begin{array}{l}200 \\
201\end{array}$ & 2. 011 & 12 & \\
\hline 3. 187 & 68 & $01 \overline{2}$ & 1. 9803 & 23 & \\
\hline 3. 154 & & $102 / \overline{2} 10$ & $\begin{array}{l}\text { 1. } 9348 \\
1.9019\end{array}$ & $\begin{array}{r}15 \\
3\end{array}$ & \\
\hline $\begin{array}{l}\text { 3. } 149 \\
3\end{array}$ & 97 & 012 & 1. 8919 & 6 & \\
\hline $\begin{array}{l}\text { 3. } 102 \\
\text { 3. } 025\end{array}$ & $\begin{array}{l}24 \\
44\end{array}$ & $\begin{array}{l}112 \\
202\end{array}$ & 1. 8635 & 21 & \\
\hline 3. 013 & 56 & 210 & 1. 8567 & 15 & \\
\hline 2. 763 & 33 & 020 & 1. 8363 & 6 & \\
\hline 2. 706 & 3 & $\frac{112}{210}$ & $\begin{array}{l}\text { 1. } 7974 \\
\text { S }\end{array}$ & 6 & \\
\hline $\begin{array}{l}2.690 \\
2.620\end{array}$ & $\begin{array}{l}7 \\
8\end{array}$ & $\begin{array}{l}\overline{2} 12 \\
21 \overline{2} / 10 \overline{3}\end{array}$ & 1. 7878 & 23 & \\
\hline \multirow[t]{2}{*}{ 2. 549} & $\begin{array}{l}2 \\
6\end{array}$ & $\begin{array}{l}021 \\
120 / \overline{1} 21\end{array}$ & $\begin{array}{l}1.7775 \\
\text { 1. } 7666\end{array}$ & $\begin{array}{l}5 \\
6\end{array}$ & \\
\hline & & & $\begin{array}{l}\text { 1. } 7471 \\
\text { 1. } 7345\end{array}$ & $\begin{array}{l}6 \\
8\end{array}$ & \\
\hline \multirow{3}{*}{$\begin{array}{l}2.474 \\
2.428 \\
2.370 \\
2.326 \\
2.301\end{array}$} & 25 & 202 & 1. 7208 & 4 & \\
\hline & $\begin{array}{l}4 \\
4\end{array}$ & $30 \overline{2}$ & 1. 7160 & 5 & \\
\hline & 2 & & $\begin{array}{l}\text { 1. } 7074 \\
\text { 1. } 68557\end{array}$ & $\begin{array}{l}7 \\
9\end{array}$ & \\
\hline 2. 274 & 4 & & 1. 6822 & 7 & \\
\hline $\begin{array}{r}2.255 \\
2.246\end{array}$ & $\begin{array}{l}4 \\
5\end{array}$ & & 1. 6732 & 9 & \\
\hline & & & 1. 6690 & $f$ & \\
\hline
\end{tabular}

a Due to the complexity of the pattern only those $h k l$ values have been given which can be assigned with reasonable certainty.

\subsection{Compound $4 \mathrm{Bi}_{2} \mathrm{O}_{3} \cdot 9 \mathrm{Nb}_{2} \mathrm{O}_{5}$}

This compound was found to be stable from about $1,070{ }^{\circ} \mathrm{C}$ to the incongruent melting point of $1,183^{\circ} \mathrm{C}$. The X-ray diffraction powder pattern, listed in table 4 , can be indexed on the basis of a hexagonal unit cell with $a=6.447 \mathrm{~A}, c=19.778 \mathrm{~A}$. There is no indication on the powder pattern that the true symmetry might have $a=\sqrt{3} 6.447 \mathrm{~A}=11.166 \mathrm{~A}$.

A compound with a similar X-ray diffraction powder pattern $\mathrm{Ba}\left(\mathrm{Nb}_{.75} \mathrm{Li}_{25}\right) \mathrm{O}_{3}$ has $a=\sqrt{3} 5.797$ $\mathrm{A}=10.040 \mathrm{~A}, c=19.072 \mathrm{~A}$; the increase in $a$ is represented by only one small peak in the powder diffraction pattern. These X-ray diffraction powder patterns are similar to those of the hexagonal com-

TABLE 4. X-ray diffraction power data for the compound $4 \mathrm{Bi}_{2} \mathrm{O}_{3} \cdot 9 \mathrm{Nb}_{2} \mathrm{O}_{5}(\mathrm{CuK} \alpha$ radiation $)$

\begin{tabular}{|c|c|c|c|c|c|}
\hline$d$ & $I / I_{0}$ & $h k l$ & $d$ & $I / I_{0}$ & $h k l$ \\
\hline $\begin{array}{l}9.86 \\
\text { 4. } 946 \\
\text { 3. } 294 \\
\text { 3. } 179 \\
\text { 3. } 063\end{array}$ & $\begin{array}{r}13 \\
4 \\
93 \\
83 \\
100\end{array}$ & $\begin{array}{l}002 \\
004 \\
006 \\
111 \\
112\end{array}$ & $\begin{array}{l}\text { 1. } 5703 \\
\text { 1. } 5324 \\
1.4931 \\
\text { 1. } 4869 \\
1.4133\end{array}$ & $\begin{array}{r}18 \\
14 \\
9 \\
5 \\
2\end{array}$ & $\begin{array}{r}1,1,11 \\
224 \\
225 \\
308 \\
0,0,14\end{array}$ \\
\hline $\begin{array}{l}\text { 2. } 895 \\
2.699 \\
2.499 \\
2.471 \\
2.308\end{array}$ & $\begin{array}{r}10 \\
73 \\
28 \\
6 \\
4\end{array}$ & $\begin{array}{l}113 \\
114 \\
115 \\
008 \\
116\end{array}$ & $\begin{array}{l}\text { 1. } 4000 \\
\text { 1. } 3554 \\
\text { 1. } 3503 \\
\text { 1. } 2496 \\
1.2340\end{array}$ & $\begin{array}{r}4 \\
3 \\
4 \\
5 \\
10\end{array}$ & $\begin{array}{r}227 \\
3,0,10 \\
228 \\
2,2,10 \\
2,1,13\end{array}$ \\
\hline $\begin{array}{l}\text { 2. } 125 \\
\text { 1. } 9778 \\
\text { 1. } 9616 \\
\text { 1. } 8610 \\
1.8158\end{array}$ & $\begin{array}{r}11 \\
7 \\
29 \\
57 \\
11\end{array}$ & $\begin{array}{r}117 \\
0,0,10 \\
118 \\
300 \\
119\end{array}$ & $\begin{array}{l}\text { 1. } 2203 \\
\text { 1. } 2162 \\
\text { 1. } 2096 \\
\text { 1. } 2003 \\
\text { 1. } 1833\end{array}$ & $\begin{array}{l}5 \\
5 \\
4 \\
3 \\
5\end{array}$ & $\begin{array}{r}1,1,15 \\
411 \\
412 \\
2,2,11 \\
414\end{array}$ \\
\hline $\begin{array}{l}\text { 1. } 6857 \\
\text { 1. } 6483 \\
\text { 1. } 6210 \\
\text { 1. } 6070 \\
1.5913\end{array}$ & $\begin{array}{r}27 \\
8 \\
39 \\
11 \\
11\end{array}$ & $\begin{array}{r}1,1,10 \\
0,0,12 \\
306 \\
221 \\
222\end{array}$ & $\begin{array}{l}1.1646 \\
1.1539 \\
1.0749 \\
1.0376 \\
1.0215 \\
1.0088\end{array}$ & $\begin{array}{l}4 \\
3 \\
2 \\
3 \\
2 \\
4\end{array}$ & $\begin{array}{r}415 \\
1,1,16 \\
330 \\
4,1,10 \\
336 \\
4,1,11\end{array}$ \\
\hline
\end{tabular}

pounds $5 \mathrm{BaO} \cdot 2 \mathrm{Nb}_{2} \mathrm{O}_{5}$ [13], $5 \mathrm{BaO}_{2} \mathrm{Ta}_{2} \mathrm{O}_{5}$ [14], Hex$\mathrm{BaTiO}_{3}[15]$ and Rhomb $\mathrm{PbO} \cdot \mathrm{Nb}_{2} \mathrm{O}_{5}$ [11]. It can be assumed that all of these compounds are structurally related, the major difference being in the stacking sequence of layers of the large cations plus $\mathrm{O}^{-2}$ ions.

\subsection{Compounds $\mathrm{Bi}_{2} \mathrm{O}_{3} \cdot 5 \mathrm{Nb}_{2} \mathrm{O}_{5}$ and $\mathrm{Bi}_{2} \mathrm{O}_{3} \cdot 6 \mathrm{Nb}_{2} \mathrm{O}_{5}$}

The compound $\mathrm{Bi}_{2} \mathrm{O}_{3} \cdot 5 \mathrm{Nb}_{2} \mathrm{O}_{5}$ was found "to be stable from room temperature to a dissociation temperature of about $1,095{ }^{\circ} \mathrm{C}$. The unindexed $\mathrm{X}$-ray diffraction powder pattern of this compound is listed in table 5 . The compound $\mathrm{Bi}_{2} \mathrm{O}_{3} \cdot 6 \mathrm{Nb}_{2} \mathrm{O}_{5}$ was found to be stable from about $1,002{ }^{\circ} \mathrm{C}$ to the incongruent melting point of $1,242{ }^{\circ} \mathrm{C}$. The unindexed X-ray diffraction powder pattern of this compound is given in table 6 . The X-ray patterns of these two compounds are very complex and obviously of low symmetry. From the general appearance of the two patterns it can be concluded that these two compounds are structurally related and probably also structurally related to pure $\mathrm{Nb}_{2} \mathrm{O}_{5}$.

TABLE 5. X-ray diffraction powder data for the compound $\mathrm{Bi}_{2} \mathrm{O}_{3} \cdot 5 \mathrm{Nb}_{2} \mathrm{O}_{5}$ (CuK $\alpha$ radiation $)$

\begin{tabular}{|c|c|c|c|c|c|}
\hline$d$ & $I / I_{0}$ & $d$ & $I / I_{0}$ & $d$ & $I / I_{0}$ \\
\hline $\begin{array}{l}12.4 \\
12.2 \\
8.55 \\
3.945 \\
3.921\end{array}$ & $\begin{array}{r}15 \\
15 \\
15 \\
100 \\
45\end{array}$ & $\begin{array}{l}\text { 3. } 319 \\
\text { 3. } 276 \\
\text { 3. } 196 \\
\text { 3. } 073 \\
\text { 3. } 062\end{array}$ & $\begin{array}{l}15 \\
15 \\
50 \\
20 \\
30\end{array}$ & $\begin{array}{l}2.843 \\
2.781 \\
2.763 \\
2.722 \\
2.601\end{array}$ & $\begin{array}{l}45 \\
60 \\
15 \\
15 \\
20\end{array}$ \\
\hline $\begin{array}{l}3.854 \\
3.599 \\
3.523 \\
3.453 \\
3.367\end{array}$ & $\begin{array}{l}30 \\
30 \\
20 \\
20 \\
80\end{array}$ & $\begin{array}{l}3.001 \\
2.964 \\
2.940 \\
2.900 \\
2.859\end{array}$ & $\begin{array}{r}90 \\
35 \\
65 \\
5 \\
30\end{array}$ & $\begin{array}{l}2.566 \\
2.487 \\
2.424 \\
2.373\end{array}$ & $\begin{array}{r}5 \\
5 \\
5 \\
45\end{array}$ \\
\hline
\end{tabular}

TABLE 6. X-ray diffraction powder data for the compound $\mathrm{Bi}_{2} \mathrm{O}_{3} \cdot 6 \mathrm{Nb}_{2} \mathrm{O}_{5}(\mathrm{Cu} K \alpha$ radiation $)$

\begin{tabular}{|c|c|c|c|c|c|}
\hline$d$ & $I / I_{0}$ & $d$ & $I / I_{0}$ & $d$ & $I / I_{0}$ \\
\hline $\begin{array}{l}7.49 \\
6.15 \\
5.92 \\
3.929 \\
3.673\end{array}$ & $\begin{array}{r}5 \\
5 \\
10 \\
100 \\
25\end{array}$ & $\begin{array}{l}\text { 3. } 206 \\
\text { 3. } 129 \\
\text { 3. } 089 \\
\text { 3. } 032 \\
\text { 3. } 000\end{array}$ & $\begin{array}{l}40 \\
25 \\
20 \\
40 \\
60\end{array}$ & $\begin{array}{l}2.736 \\
2.596 \\
2.592 \\
2.439 \\
2.402\end{array}$ & $\begin{array}{r}10 \\
40 \\
35 \\
5 \\
10\end{array}$ \\
\hline $\begin{array}{l}3.619 \\
\text { 3. } 455 \\
3.442 \\
\text { 3. } 310 \\
\text { 3. } 274\end{array}$ & $\begin{array}{l}15 \\
30 \\
35 \\
10 \\
20\end{array}$ & $\begin{array}{l}2.964 \\
2.930 \\
2.854 \\
2.788 \\
2.773\end{array}$ & $\begin{array}{l}15 \\
40 \\
10 \\
30 \\
55\end{array}$ & $\begin{array}{l}2.386 \\
2.352 \\
2.294 \\
2.275\end{array}$ & $\begin{array}{r}10 \\
10 \\
5 \\
10\end{array}$ \\
\hline
\end{tabular}

\section{6. $\mathrm{Nb}_{2} \mathrm{O}_{5}$}

The stability relations of the various reported polymorphs of $\mathrm{Nb}_{2} \mathrm{O}_{5}$ have been summarized by several workers $[16,17,18,19] . \mathrm{Bi}_{2} \mathrm{O}_{3}$, unlike $\mathrm{PbO}$ [11], has no catalytic action on the thermal stability of the various modifications of $\mathrm{Nb}_{2} \mathrm{O}_{5}$. Since it has been concluded $[11,16,19]$ that the high-temperature monoclinic form of $\mathrm{Nb}_{2} \mathrm{O}_{5}\left(\mathrm{H}-\mathrm{Nb}_{2} \mathrm{O}_{5}\right)$ is the only stable form, no phase transformation temperature has been indicated. The X-ray powder pattern and unit cell dimensions of the stable form were previously reported [11]. 


\section{Discussion of Phase Equilibria}

The phase equilibrium diagram of the binary system $\mathrm{Bi}_{2} \mathrm{O}_{3}-\mathrm{Nb}_{2} \mathrm{O}_{5}$ is shown in figure 1 . The experimental data from which this diagram was constructed are given in table 7 . The designation Per. in table 7 stands for the perovskite structure type and signifies that the material which crystallizes in this structure type must have been in the liquid state when quenched (see discussion of metastable compounds in section 5). The system contains one compound which melts congruently, $\mathrm{Bi}_{2} \mathrm{O}_{3} \cdot \mathrm{Nb}_{2} \mathrm{O}_{5}$; three compounds which melt incongruently, $5 \mathrm{Bi}_{2} \mathrm{O}_{3} \cdot 3 \mathrm{Nb}_{2} \mathrm{O}_{5}, \quad 4 \mathrm{Bi}_{2} \mathrm{O}_{3} \cdot 9 \mathrm{Nb}_{2} \mathrm{O}_{5}$, and $\mathrm{Bi}_{2} \mathrm{O}_{3} \cdot 6 \mathrm{Nb}_{2} \mathrm{O}_{5}$; and one compound which dissociates before melting, $\mathrm{Bi}_{2} \mathrm{O}_{3} \cdot 5 \mathrm{Nb}_{2} \mathrm{O}_{5}$. In addition $\mathrm{Bi}_{2} \mathrm{O}_{3} \cdot \mathrm{Nb}_{2} \mathrm{O}_{5}$ has two polymorphs and $4 \mathrm{Bi}_{2} \mathrm{O}_{3} \cdot 9 \mathrm{Nb}_{2} \mathrm{O}_{5}$ and $\mathrm{Bi}_{2} \mathrm{O}_{3} \cdot 6 \mathrm{Nb}_{2} \mathrm{O}_{5}$ both apparently have minimum temperatures of stability.

The high-temperature cubic polymorph of $\mathrm{Bi}_{2} \mathrm{O}_{3}$ is stabilized by the addition of $\mathrm{Nb}_{2} \mathrm{O}_{5}$ in solid solution. When specimens containing $1,2,3$, and 4 mole percent $\mathrm{Nb}_{2} \mathrm{O}_{5}$ are quenched trom the region between the monoclinic-cubic phase transformation and the solidus temperature the resultant material is tetragonal with the unit cell dimensions shown in table 8. However, high-temperature X-ray patterns show the compositions to be really cubic at these temperatures. The unit cell dimensions of the cubic and pseudocubic solid solutions from 5 mole percent $\mathrm{Nb}_{2} \mathrm{O}_{5}$ to 25 mole percent $\mathrm{Nb}_{2} \mathrm{O}_{5}$ are also given in table 8 .

TABLE 7. Experimental data for compositions in the binary system $\mathrm{Bi}_{2} \mathrm{O}_{3}-\mathrm{Nb}_{2} \mathrm{O}_{5}$

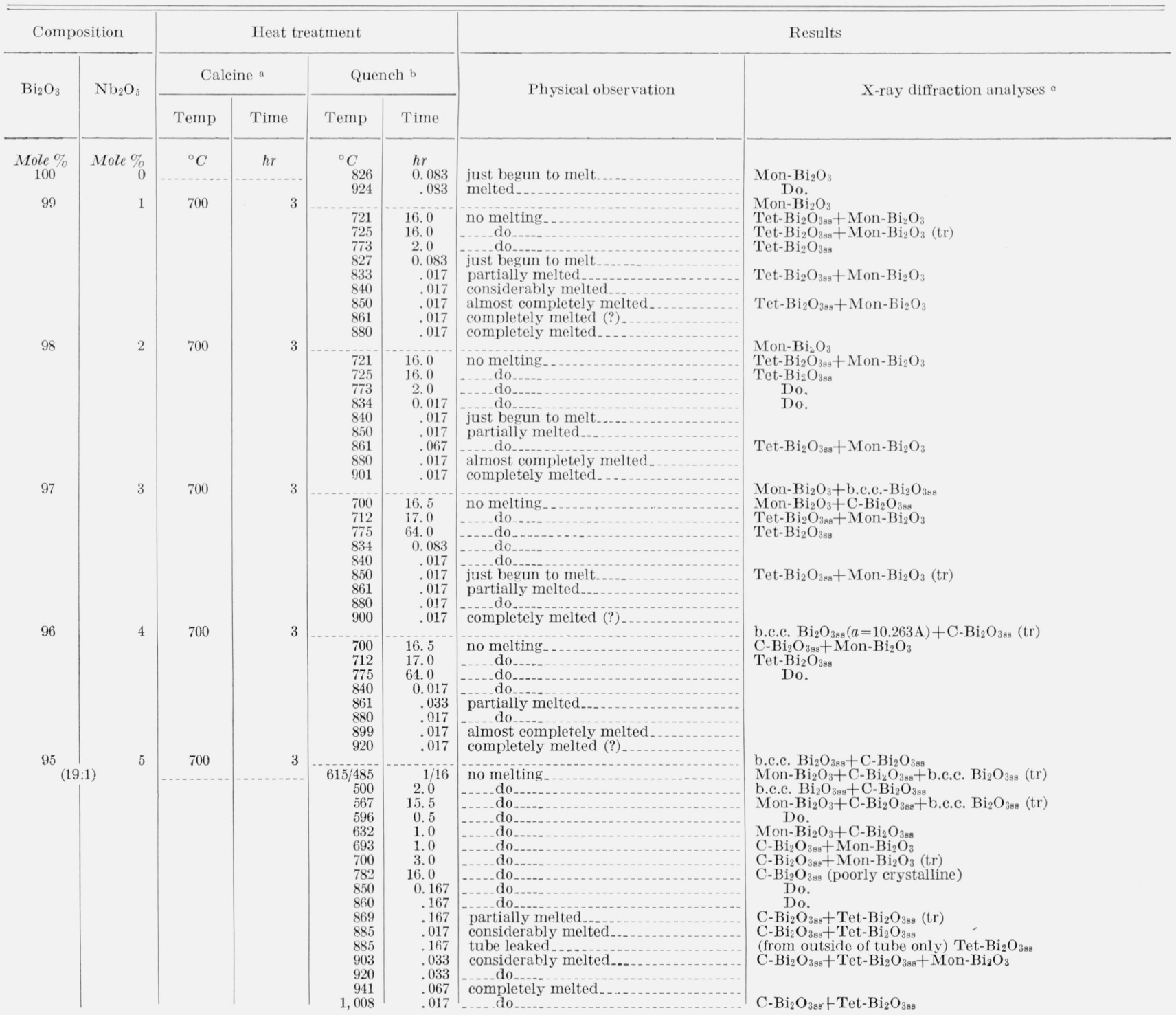

See footnotes at end of table. 
TABLE 7. Experimental data for compositions in the binary system $\mathrm{Bi}_{2} \mathrm{O}_{3}-\mathrm{Nb}_{2} \mathrm{O}_{5}-\mathrm{Continued}$

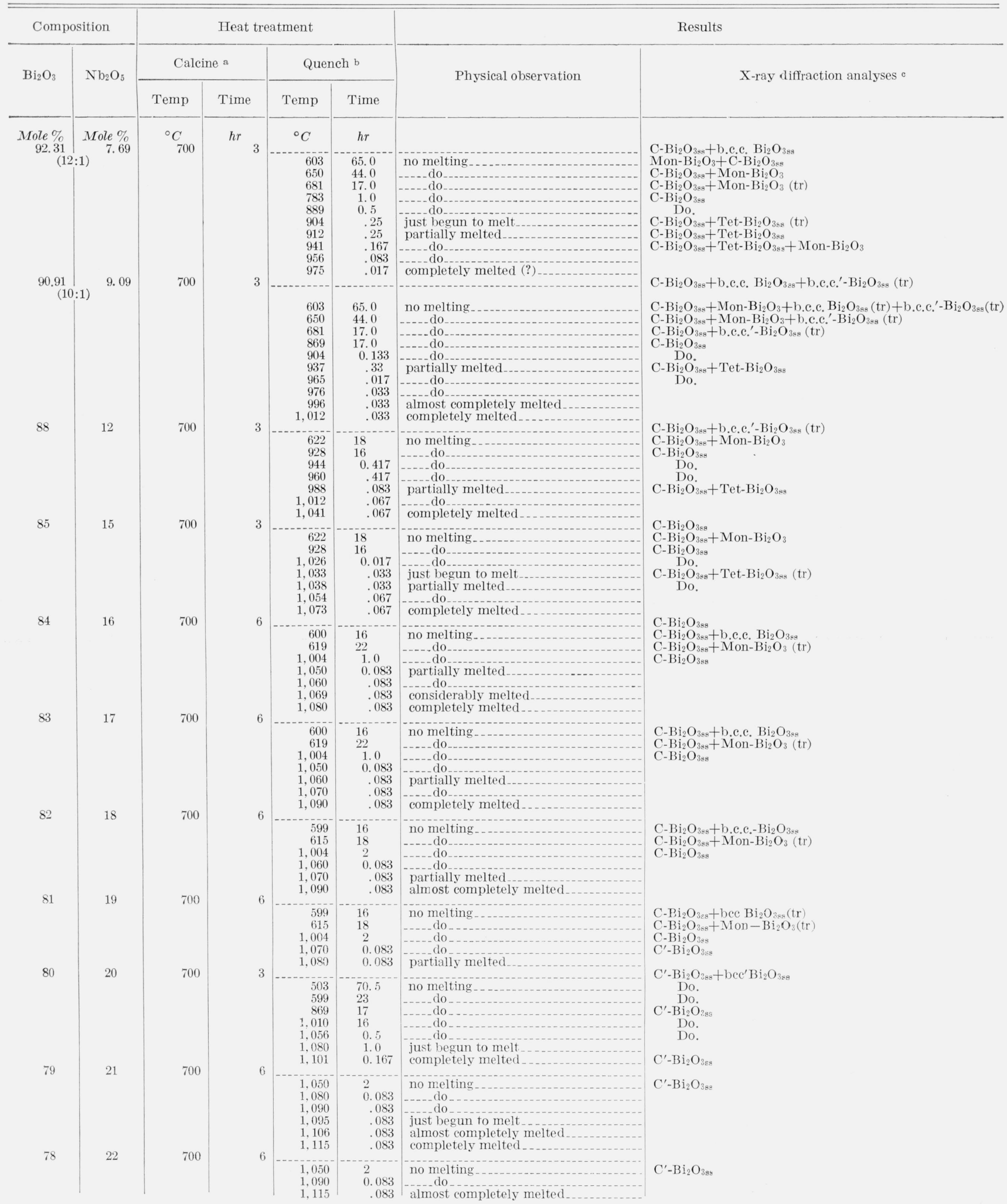

See footnotes at end of table. 
TABLE 7. Experimental data for compositions in the binary system $\mathrm{Bi}_{2} \mathrm{O}_{3}-\mathrm{Nb}_{2} \mathrm{O}_{5}-$ Continued

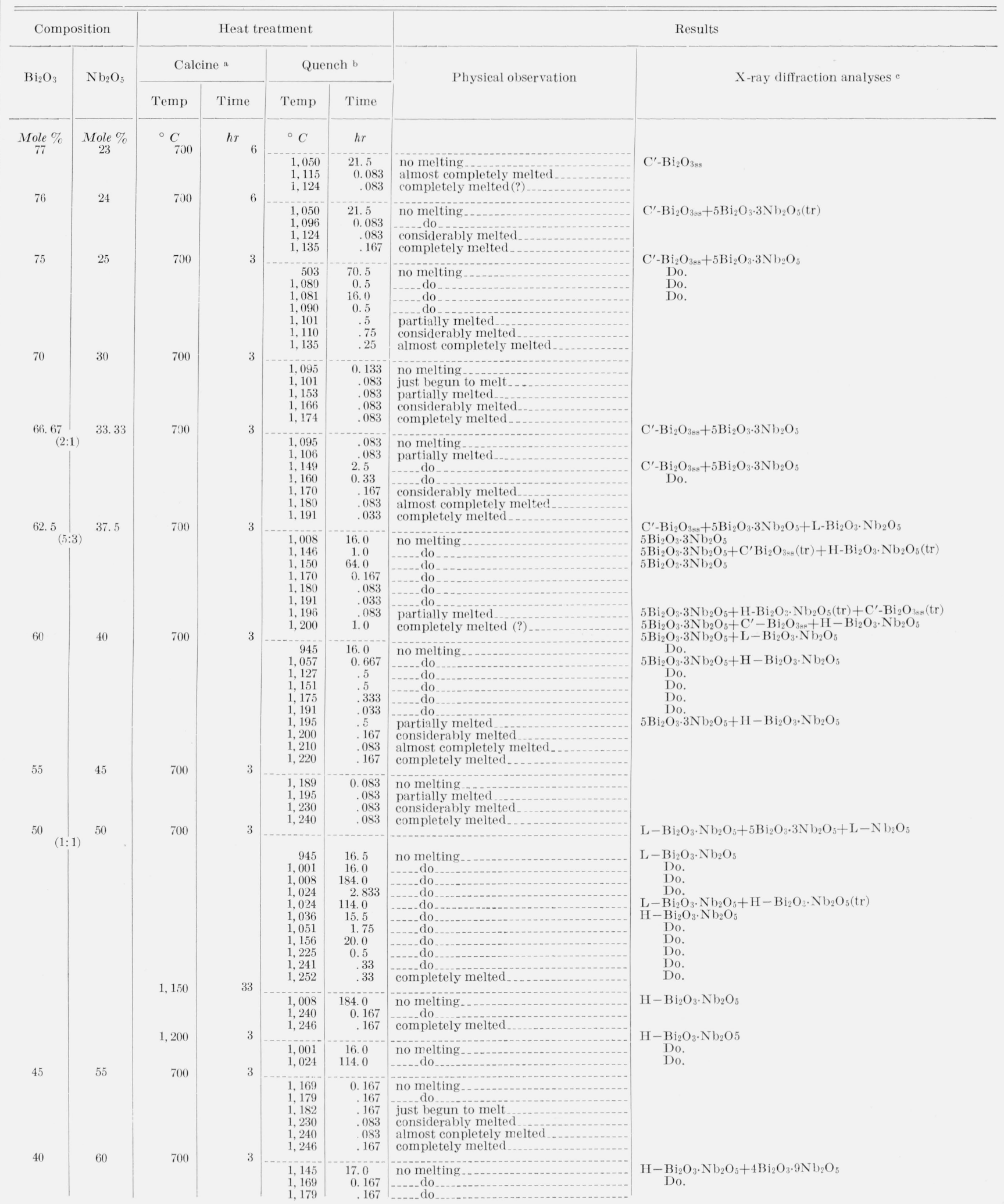

See footnotes at end of table. 
TABLE 7. Experimental data for compositions in the binary system $\mathrm{Bi}_{2} \mathrm{O}_{3}-\mathrm{Nb}_{2} \mathrm{O}_{5}-\mathrm{Continued}$

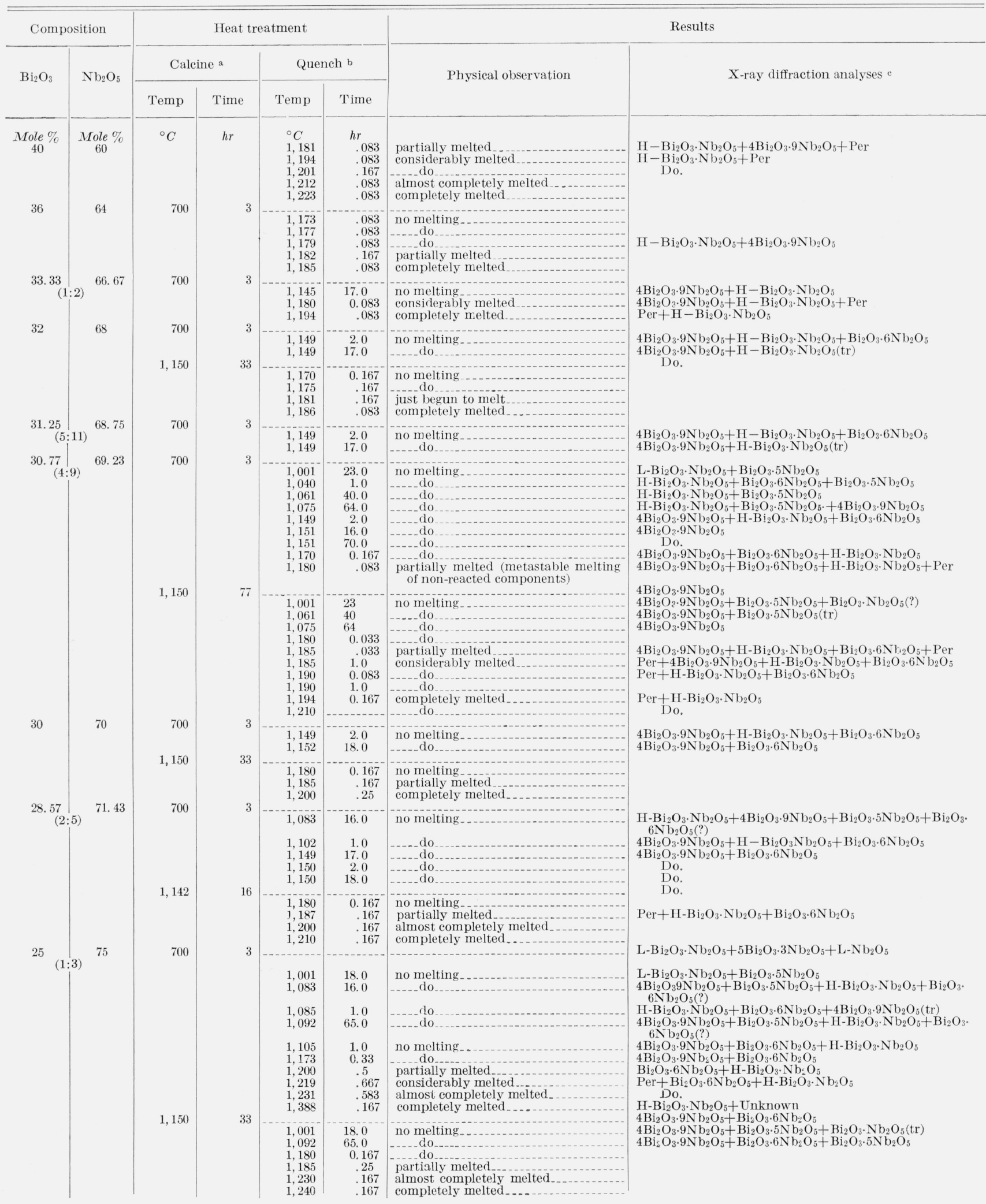

See footnotes at end of table. 
TABLE 7. Experimental data for compositions in the binary system $\mathrm{Bi}_{2} \mathrm{O}_{3}-\mathrm{Nb}_{2} \mathrm{O}_{5}-\mathrm{Continued}$

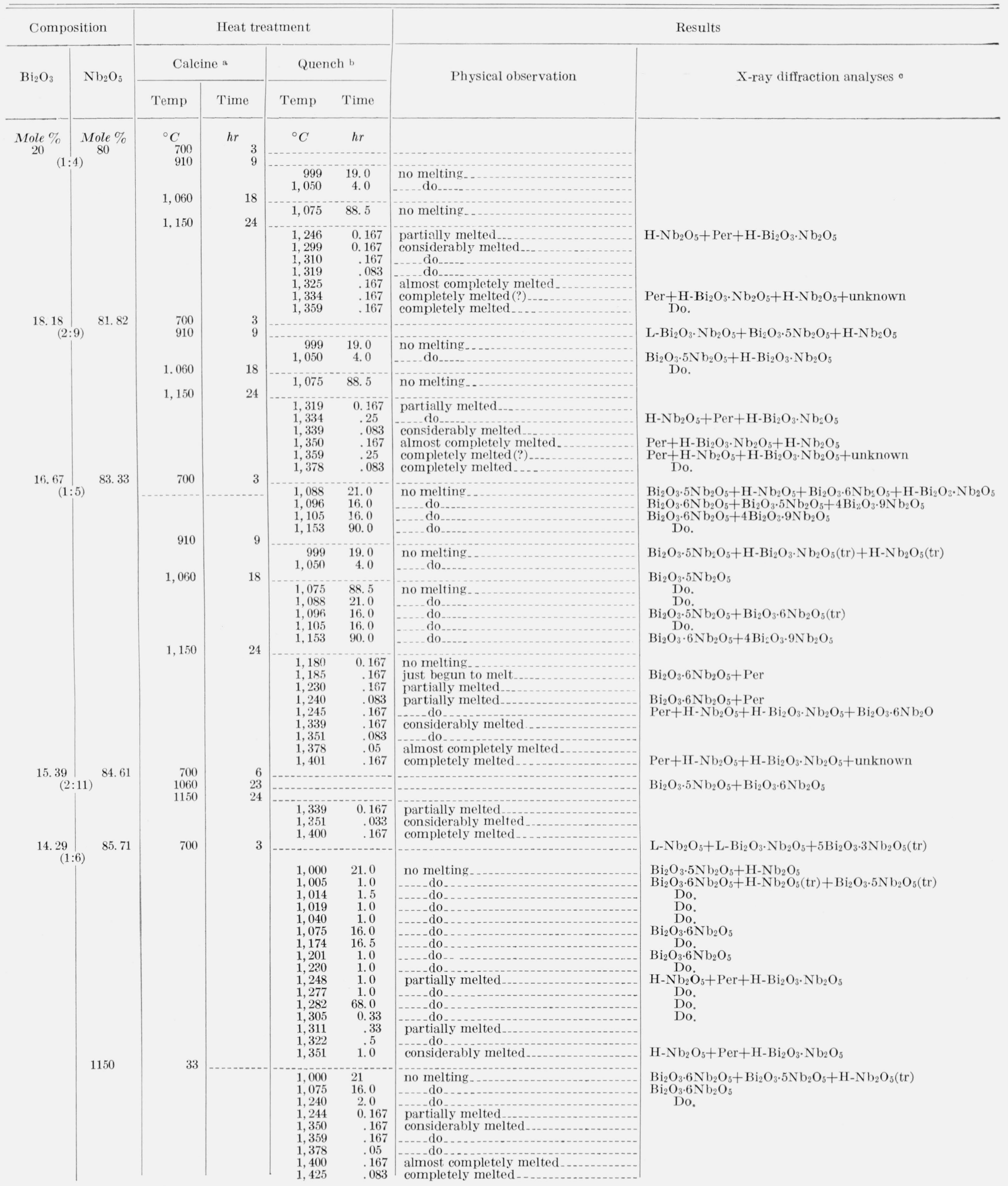

See footnotes at end of table. 
TABLE 7. Experimental data for compositions in the binary system $\mathrm{Bi}_{2} \mathrm{O}_{3}-\mathrm{Nb}_{2} \mathrm{O}_{5}-\mathrm{Continued}$

\begin{tabular}{|c|c|c|c|c|c|c|c|}
\hline \multicolumn{2}{|c|}{ Composition } & \multicolumn{4}{|c|}{ Heat treatment } & \multicolumn{2}{|r|}{ Results } \\
\hline \multirow{2}{*}{$\mathrm{Bi}_{2} \mathrm{O}_{3}$} & \multirow{2}{*}{$\mathrm{Nb}_{2} \mathrm{O}_{5}$} & \multicolumn{2}{|c|}{ Calcine a } & \multicolumn{2}{|c|}{ Quench b } & \multirow{2}{*}{ Physical observation } & \multirow{2}{*}{$\mathrm{X}$-ray diffraction analyses $\mathrm{c}$} \\
\hline & & Temp & Time & Temp & Time & & \\
\hline $\begin{array}{l}\text { Mole } \% \\
\quad 9.09\end{array}$ & $\begin{array}{r}\text { Mole \% } \\
90.91\end{array}$ & ${ }^{\circ} C_{700}$ & $h r$ & ${ }^{\circ} \mathrm{C}$ & $h r$ & 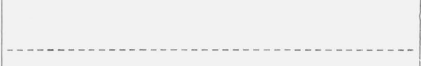 & $\mathrm{L}-\mathrm{Nb}_{2} \mathrm{O}_{5}+\mathrm{L}-\mathrm{Bi}_{2} \mathrm{O}_{3} \cdot \mathrm{Nb}_{2} \mathrm{O}_{5}+5 \mathrm{Bi}_{2} \mathrm{O}_{3} \cdot 3 \mathrm{Nb}_{2} \mathrm{O}_{5}(\mathrm{tr})$ \\
\hline (1. & & 150 & 4 & $\begin{array}{r}898 \\
1,005 \\
1,014 \\
1,019 \\
1,284 \\
1,295 \\
1,301 \\
1,310\end{array}$ & $\begin{array}{r}16.0 \\
1.0 \\
1.5 \\
1.0 \\
0.5 \\
.5 \\
.33 \\
.33\end{array}$ & $\begin{array}{l}\text { no melting } \\
\text { partially melted } \\
\\
\\
\end{array}$ & $\begin{array}{l}\mathrm{Bi}_{2} \mathrm{O}_{3} \cdot 5 \mathrm{Nb}_{2} \mathrm{O}_{5}+\mathrm{H}-\mathrm{Nb}_{2} \mathrm{O}_{5} \\
\mathrm{Bi}_{2} \mathrm{O}_{3} \cdot 6 \mathrm{Nb}_{2} \mathrm{O}_{5}+\mathrm{H}-\mathrm{Nb}_{2} \mathrm{O}_{5} \\
\text { Do. } \\
\text { Do. }\end{array}$ \\
\hline & & 1,150 & 24 & $\begin{array}{l}1,240 \\
1,245 \\
1,401 \\
1,426 \\
1,451\end{array}$ & $\begin{array}{r}0.167 \\
.167 \\
.083 \\
.083 \\
.083\end{array}$ & $\begin{array}{l}\text { no melting } \\
\text { partially melted } \\
\text { considerably melted } \\
\text { completely melted. }\end{array}$ & $\mathrm{Bi}_{2} \mathrm{O}_{3} \cdot 6 \mathrm{Nb}_{2} \mathrm{O}_{5}+\mathrm{H}-\mathrm{Nb}_{2} \mathrm{O}_{5}$ \\
\hline 5 & 95 & $\begin{array}{r}700 \\
1,150\end{array}$ & $\begin{array}{r}3 \\
24\end{array}$ & 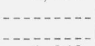 & (n) & $\mid$ & \\
\hline 0 & 100 & & & $\begin{array}{l}1,240 \\
1,245 \\
1,425 \\
1,451 \\
1,480 \\
1,480 \\
1,484 \\
1,486 \\
1,489 \\
1,491\end{array}$ & $\begin{array}{l}0.167 \\
.167 \\
.083 \\
.083 \\
.083 \\
.083 \\
.083 \\
.083 \\
.083 \\
.083\end{array}$ & $\begin{array}{l}\text { no melting } \\
\text { just begun to melt } \\
\text { partially melted } \\
\text { considerably melted. } \\
\text { completely melted. } \\
\text { no melting } \\
\text { completely melted }\end{array}$ & $\mathrm{H}-\mathrm{Nb}_{2} \mathrm{O}_{5}+\mathrm{Bi}_{2} \mathrm{O}_{3} \cdot 6 \mathrm{Nb}_{2} \mathrm{O}_{5}$ \\
\hline
\end{tabular}

a All calcined specimens were heated and cooled at the rate of approximately $4^{\circ} \mathrm{min}$ All specimens were first calcined at $700{ }^{\circ} \mathrm{C}$ and then small portions of this calcine were recalcined at one or more desired higher temperatures.

b All specimens were quenched in sealed Pt tubes.

c The phases identified are given in the order of the amount present at room the phases identified are given in the present at room temperature. The phases are not necessarily those present at the temperature to
which the specimen was heated. C-cubic, $\mathrm{C}^{\prime}-$ pseudocubic, b.c.c.-body-

TABLE 8. Unit cell dimensions of tetragonal and cubic $\mathrm{Bi}_{2} \mathrm{O}_{3}$ solid solutions

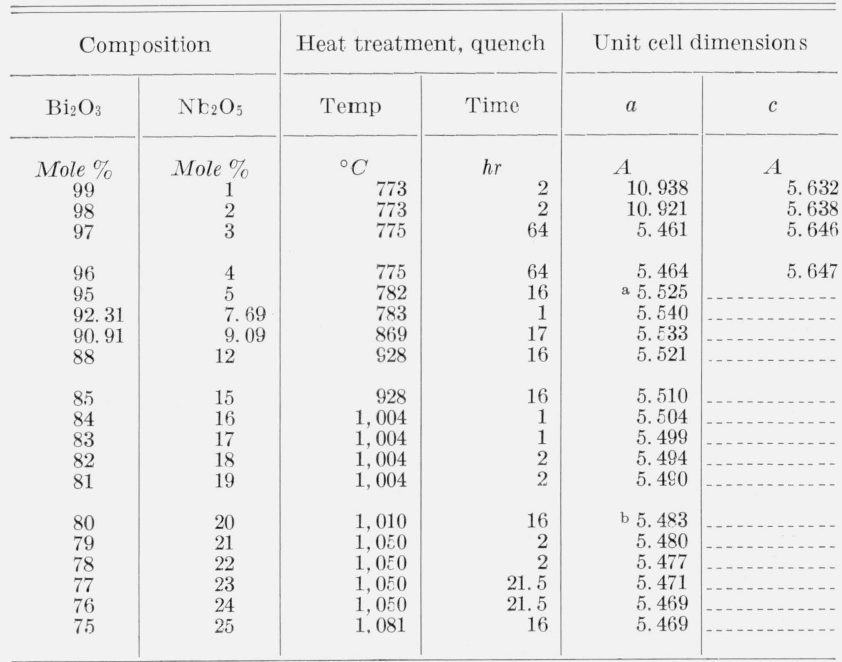

a This material was poorly crystalline and the value given is an average-value for the cubic and tetragonal phases.

b From 20 to 25 mole percent $\mathrm{Nb}_{2} \mathrm{O}_{5}$ the parameters represent the values measured for the pseudocubic cell.

The melting points of the solid solutions increase from the melting point of pure $\mathrm{Bi}_{2} \mathrm{O}_{3}, 825^{\circ} \mathrm{C}[20]$, to about $1,055{ }^{\circ} \mathrm{C}$ at 17 mole percent $\mathrm{Nb}_{2} \mathrm{O}_{5}$. A morphotropic transformation occurs in the solid centered cubic ( $a=10.263 \mathrm{~A})$, b.c.c. - body-centered cubic $(a=10.15-10.19 \mathrm{~A})$, Tet-tetragonal, Mon-monoclinic, L-low-temperature polymorph, $\mathrm{H}$ - hightemperature polymorph, Per-perovskite $(a=3.94 \mathrm{~A})$, a composition of approximately $\mathrm{Bi}_{2} \mathrm{O}_{3}: 3 \mathrm{Nb}_{2} \mathrm{O}_{5}$. always metastable in this system and occurs only upon quenching the liquid, ss-solid solution, tr-trace, just barely discernable in X-ray pattern.

solution at this point curving to a eutectoid at about $610{ }^{\circ} \mathrm{C}$ and 19.5 mole percent $\mathrm{Nb}_{2} \mathrm{O}_{5}$. The cubicmonoclinic transformation temperature is lowered from about $730{ }^{\circ} \mathrm{C}$ to the above-mentioned eutectoid although there is very little solid solution in the monoclinic phase.

The solid solution higher in $\mathrm{Nb}_{2} \mathrm{O}_{5}$ content is designated $\mathrm{C}^{\prime}$ ss in table 7 . It is apparently only pseudocubic with several very small superstructure peaks in the X-ray diffraction pattern corresponding to $d$ spacings of about $8.4 \mathrm{~A}, 2.69 \mathrm{~A}$, and $2.35 \mathrm{~A}$. The two phase region between the two solid solution fields is too narrow to be found by experimentation and is shown as dashed lines in figure 1. The C'ss is apparently stable from room temperature to the solidus which extends to about $1,096{ }^{\circ} \mathrm{C}$ at 23 mole percent $\mathrm{Nb}_{2} \mathrm{O}_{5}$. The peritectic for this solidus occurs at about 20 mole percent $\mathrm{Nb}_{2} \mathrm{O}_{5}$.

The liquidus rises smoothly from the $1,096{ }^{\circ} \mathrm{C}$ peritectic to another peritectic at 36.5 mole percent $\mathrm{Nb}_{2} \mathrm{O}_{5}$ and $1,193{ }^{\circ} \mathrm{C}$ corresponding to the incongruent melting temperature of the compound $5 \mathrm{Bi}_{2} \mathrm{O}_{3} \cdot 3 \mathrm{Nb}_{2} \mathrm{O}_{5}$. There is little or no solid solution on either side of this compound, or any other of the compounds in the binary system, as shown by the similarity of the unit cell dimensions of the pure compound to those of the same compound in a two phase region.

The liquidus again rises smoothly from the 1,193 ${ }^{\circ} \mathrm{C}$ peritectic to the congruent melting point of $\mathrm{Bi}_{2} \mathrm{O}_{3} \cdot \mathrm{Nb}_{2} \mathrm{O}_{5}$ at $1,245{ }^{\circ} \mathrm{C}$. This compound was observed to crystallize in two polymorphic forms. 
The low-temperature orthorhombic form was found to transform to the triclinic form at-about $1,020^{\circ} \mathrm{C}$. However this phase transformation could not be reversed. Neither polymorph appeared changed after $184 \mathrm{hr}$ at $1,008^{\circ} \mathrm{C}$, but a small amount of the high-temperature form was present in the original low form after $114 \mathrm{hr}$ at $1,024{ }^{\circ} \mathrm{C}$ (see table 7 ). Because of the inability to reverse the phase transformation the polymorphic change is shown as a dashed line in figure 1.
The liquidus curve falls smoothly from $1,245{ }^{\circ} \mathrm{C}$ to a eutectic at $1,180{ }^{\circ} \mathrm{C}$ and about 64 mole percent $\mathrm{Nb}_{2} \mathrm{O}_{5}$. The liquidus then rises very shallowly to a peritectic point at about 68 mole percent $\mathrm{Nb}_{2} \mathrm{O}_{5}$ and $1,183{ }^{\circ} \mathrm{C}$, the incongruent melting temperature of the $4 \mathrm{Bi}_{2} \mathrm{O}_{3} \cdot 9 \mathrm{Nb}_{2} \mathrm{O}_{5}$ compound. This compound needs a long period of heating time at relatively high temperatures in order to form a single phase. It also takes a relatively long time to be completely transformed to liquid plus the $\mathrm{Bi}_{2} \mathrm{O}_{3} \cdot 6 \mathrm{Nb}_{2} \mathrm{O}_{5}$ com-

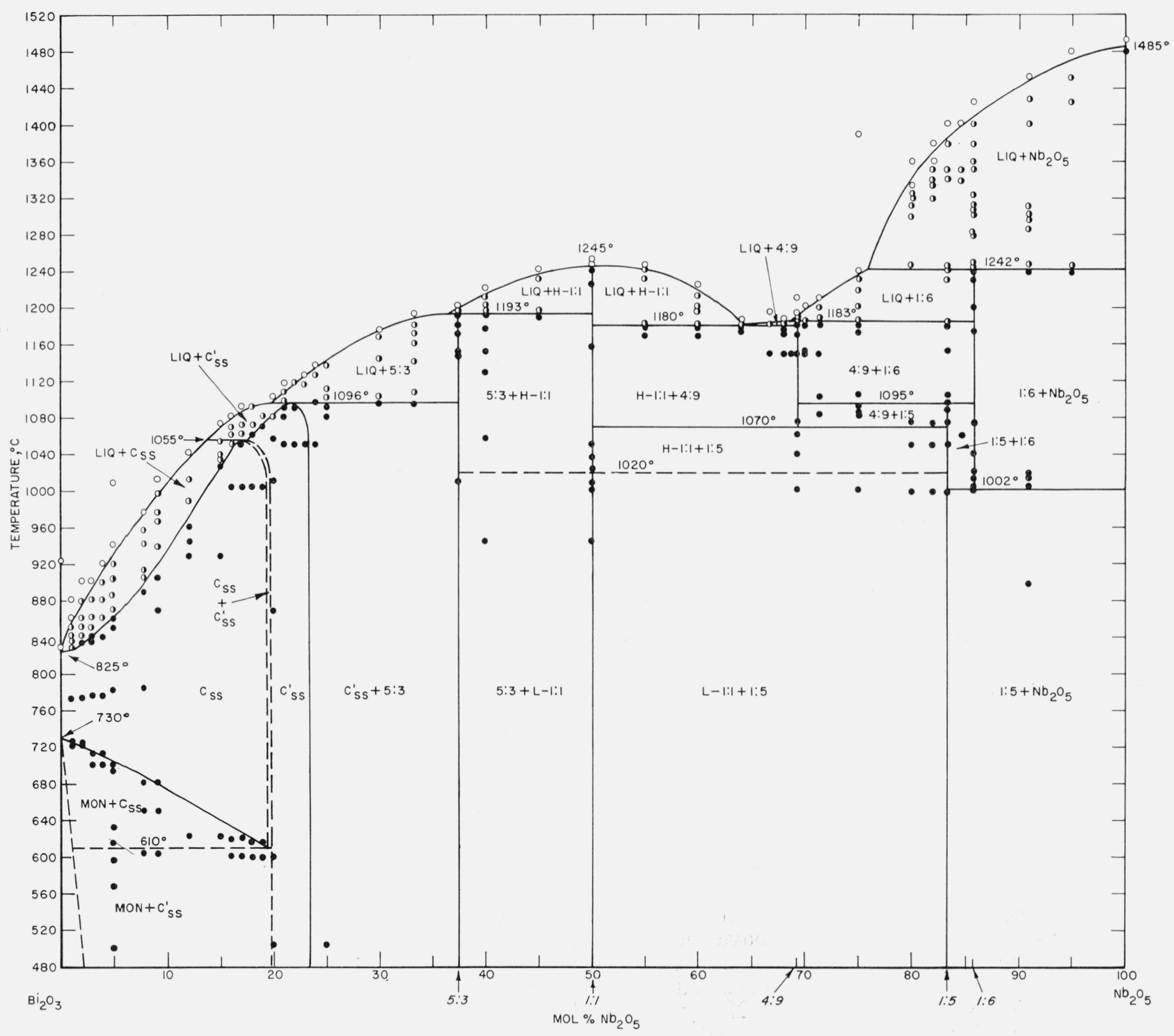

Figure 1. Phase equilibrium diagram for the system $\mathrm{Bi}_{2} \mathrm{O}_{3}-\mathrm{Nb}_{2} \mathrm{O}_{5}$

9-no melting

- partially melted

- completely melted

L-low temperature modification

$\mathrm{H}-$ high temperature modification

C-cubic

$\mathrm{C}^{\prime}$-pseudocubic

Mon-monoclinic

LIQ-liquid 
pound (see table 7 ). The hexagonal $4 \mathrm{Bi}_{2} \mathrm{O}_{3} \cdot 9 \mathrm{Nb}_{2} \mathrm{O}_{5}$ compound is not rormed at all-below about $1,070{ }^{\circ} \mathrm{C}$. Specimens preheated to form a single phase are slowly decomposed to triclinic $\mathrm{Bi}_{2} \mathrm{O}_{3} \cdot \mathrm{Nb}_{2} \mathrm{O}_{5}$ and the $\mathrm{Bi}_{2} \mathrm{O}_{5} \cdot 5 \mathrm{Nb}_{2} \mathrm{O}_{5}$ compound, when heated below about $1,070{ }^{\circ} \mathrm{C}$. The $4 \mathrm{Bi}_{2} \mathrm{O}_{3} \cdot 9 \mathrm{Nb}_{2} \mathrm{O}_{5}$ compound can therefore be concluded to have a minimum temperature of stability at about $1,070{ }^{\circ} \mathrm{C}$.

The compound $\mathrm{Bi}_{2} \mathrm{O}_{3} \cdot 5 \mathrm{Nb}_{2} \mathrm{O}_{5}$ was found to have a maximum temperature of stability of about $1,095{ }^{\circ} \mathrm{C}$. The preformed compound slowly decomposed to $4 \mathrm{Bi}_{2} \mathrm{O}_{3} \cdot 9 \mathrm{Nb}_{2} \mathrm{O}_{5}$ and $\mathrm{Bi}_{2} \mathrm{O}_{3} \cdot 6 \mathrm{Nb}_{2} \mathrm{O}_{5}$ above this temperature, while the original $700^{\circ}$ calcined material showed no $\mathrm{Bi}_{2} \mathrm{O}_{3} .5 \mathrm{Nb}_{2} \mathrm{O}_{5}$ at all when heated much above $1,095{ }^{\circ} \mathrm{C}$. The compound $\mathrm{Bi}_{2} \mathrm{O}_{3} \cdot 6 \mathrm{Nb}_{2} \mathrm{O}_{5}$ was found to have a minimum temperature of stability at about $1,002{ }^{\circ} \mathrm{C}$. A specimen heated for $21 \mathrm{hr}$ at $1,000{ }^{\circ} \mathrm{C}$ contained only $\mathrm{Bi}_{2} \mathrm{O}_{3} \cdot 5 \mathrm{Nb}_{2} \mathrm{O}_{5}$ and $\mathrm{H}-\mathrm{Nb}_{2} \mathrm{O}_{5}$, while heating for $1 \mathrm{hr}$ at $1,005^{\circ} \mathrm{C}$ was enough to form the $\mathrm{Bi}_{2} \mathrm{O}_{3} \cdot 6 \mathrm{Nb}_{2} \mathrm{O}_{5}$ phase with only traces of the other two. The preformed $\mathrm{Bi}_{2} \mathrm{O}_{3} \cdot 6 \mathrm{Nb}_{2} \mathrm{O}_{5}$ compound showed definite traces of $\mathrm{Bi}_{2} \mathrm{O}_{3} \cdot 5 \mathrm{Nb}_{2} \mathrm{O}_{5}$ and $\mathrm{H}-\mathrm{Nb}_{2} \mathrm{O}_{5}$ after reheating for $21 \mathrm{hr}$ at $1,000{ }^{\circ} \mathrm{C}$.

$\mathrm{Bi}_{2} \mathrm{O}_{3} \cdot 6 \mathrm{Nb}_{2} \mathrm{O}_{5}$ was found to melt incongruently at $1,242{ }^{\circ} \mathrm{C}$ to a liquid containing approximately 76 mole percent $\mathrm{Nb}_{2} \mathrm{O}_{5}$ plus crystalline $\mathrm{Nb}_{2} \mathrm{O}_{5}$ with little or no $\mathrm{Bi}_{2} \mathrm{O}_{3}$ in solid solution. The liquidus between the $1,183{ }^{\circ} \mathrm{C}$ peritectic and the $1,242{ }^{\circ} \mathrm{C}$ peritectic is essentially a straight line. The liquidus rises smoothly from the last peritectic to the melting point of $\mathrm{Nb}_{2} \mathrm{O}_{5}$, found to be $1,485{ }^{\circ} \mathrm{C}$ for the batch of $\mathrm{Nb}_{2} \mathrm{O}_{5}$ used for this study. As this $\mathrm{Nb}_{2} \mathrm{O}_{5}$ is essentially Ta free it is not surprising that this melting point is several degrees lower than that previously reported $[11,13,16,19]$.

It is interesting to note that although both $\mathrm{BaO}$ and $\mathrm{PbO}$ enter into solid solution in $\mathrm{Nb}_{2} \mathrm{O}_{5}[11,13]$ the $\mathrm{Bi}_{2} \mathrm{O}_{3}$ does not. Considering that the radius and polarizability of $\mathrm{Pb}^{+2}$ and $\mathrm{Bi}^{+3}$ are very similar [20] this fact must be dependent on the difference in valence. It should also be noted that unlike $\mathrm{PbO}$ [11] $\mathrm{Bi}_{2} \mathrm{O}_{3}$ has no catalytic effect upon the temperature of the metastable phase transformations in $\mathrm{Nb}_{2} \mathrm{O}_{5}$.

\section{Metastable Phases}

\subsection{The Perovskite Phase}

When compositions containing more than 50 mole percent $\mathrm{Nb}_{2} \mathrm{O}_{5}$ were quenched from above the solidus a metastable phase always formed from the liquid. The maximum amount of this phase occurred around the composition $\mathrm{Bi}_{2} \mathrm{O}_{3}: 3 \mathrm{Nb}_{2} \mathrm{O}_{5}$. The X-ray diffraction pattern of this phase could be interpreted as that of a poorly crystalline cubic perovskite with $a \cong 3.94 \mathrm{~A}$. Specimens quenched from above about $1,380{ }^{\circ} \mathrm{C}$ (well above the liquidus) contained another metastable phase which had an X-ray diffraction pattern similar to the cubic perovskite, but with extra lines. The metastable perovskite in this system can be compared with the distorted perovskite compound $\mathrm{La}_{2} \mathrm{O}_{3}$. $3 \mathrm{Nb}_{2} \mathrm{O}_{5}$, previously reported [21].

\subsection{The System $\mathrm{Bi}_{2} \mathrm{O}_{3}-\mathrm{Nb}_{2} \mathrm{O}_{5}-\mathrm{Alcohol}$}

A large number of metastable phases were found to occur in the $\mathrm{Bi}_{2} \mathrm{O}_{3}-\mathrm{Nb}_{2} \mathrm{O}_{5}$ system if either methyl or ethyl alcohol was used for wet mixing of the end members, and the resultant material was pressed into a pellet and fired without first thoroughly drying the mixture. Two separate body centered cubic phases were observed in mixtures containing 3 to 25 mole percent $\mathrm{Nb}_{2} \mathrm{O}_{5}$ which had been wet mixed with methyl alcohol. The first phase, labeled b.c.c. in table 7, had a unit cell dimension of $a=10.263 \mathrm{~A}$. This phase decomposed quickly in quench runs above $750{ }^{\circ} \mathrm{C}$ and did not affect the melting point measurements. However specimens containing 16 to 24 mole percent $\mathrm{Nb}_{2} \mathrm{O}_{5}$ originally mixed with methyl alcohol contained large amounts of a second body centered cubic phase (labeled b.c.c.' in table 7) with $a$ about 10.15 to $10.19 \mathrm{~A}$. These specimens were found to dissociate to unknown phases which had metastable melting points several hundred degrees below the melting values of specimens prepared without alcohol, and had to be discarded. For these latter compositions only the dry-mixed specimens are reported in table 7 . Other unknown phases were found in mixtures containing 1 to 4 mole percent $\mathrm{Nb}_{2} \mathrm{O}_{5}$ which had been wet-mixed in ethyl alcohol and were also discarded for table 7 .

It seems likely that $\mathrm{Bi}_{2} \mathrm{O}_{3}$ forms a series of complex compounds with methyl and ethyl alcohol and can incorporate $\mathrm{Nb}_{2} \mathrm{O}_{5}$ into these compounds. The first b.c.c. phase $(a=10.263 \mathrm{~A})$ seems to contain little or no $\mathrm{Nb}_{2} \mathrm{O}_{5}$ and probably contains only $\mathrm{Bi}_{2} \mathrm{O}_{3}$ and alcohol or carbon. The second (b.c.c.') phase apparently contained about 12 to 15 mole percent $\mathrm{Nb}_{2} \mathrm{O}_{5}$ (plus alcohol or carbon). The body-centered cubic phase appears to be built up by spheres of $\mathrm{Bi}^{+3}$ and $\mathrm{O}^{-2}$ ions with a large tetrahedrally coordinated hole in the center $[6,8]$. This host lattice, by itself apparently thermodynamically unstable, is stabilized in some cases by the addition of a second component in the central hole. It is possible that this phase may therefore be a clathrate type compound. A more complete study by high-temperature X-ray diffraction, of the body-centered cubic phase with a large number of other oxides will be discussed in a future publication.

\section{Summary}

The system $\mathrm{Bi}_{2} \mathrm{O}_{3}-\mathrm{Nb}_{2} \mathrm{O}_{5}$ was studied by means of solid state reactions, fusion characteristics, and X-ray diffraction data. The existence of five compounds in this system was shown. They are: $5 \mathrm{Bi}_{2} \mathrm{O}_{3} \cdot 3 \mathrm{Nb}_{2} \mathrm{O}_{5}$, which melts incongruently at $1,193{ }^{\circ} \mathrm{C}$ to $\mathrm{Bi}_{2} \mathrm{O}_{3} \cdot \mathrm{Nb}_{2} \mathrm{O}_{5}$ and liquid containing about 36.5 mole percent $\mathrm{Nb}_{2} \mathrm{O}_{5}$; $\mathrm{Bi}_{2} \mathrm{O}_{3} \cdot \mathrm{Nb}_{2} \mathrm{O}_{5}$ which melts congruently at $1,245{ }^{\circ} \mathrm{C}$, and has a phase transition (irreversible in laboratory time) at about $1,020{ }^{\circ} \mathrm{C}$ from a low-temperature orthorhombic structure to a high temperature triclinic form; $4 \mathrm{Bi}_{2} \mathrm{O}_{3} \cdot 9 \mathrm{Nb}_{2} \mathrm{O}_{5}$ which has a minimum temperature of stability at $1,070{ }^{\circ} \mathrm{C}$ and melts incongruently to $\mathrm{Bi}_{2} \mathrm{O}_{3} \cdot 6 \mathrm{Nb}_{2} \mathrm{O}_{5}$ and liquid containing about 68 mole percent $\mathrm{Nb}_{2} \mathrm{O}_{5} ; \mathrm{Bi}_{2} \mathrm{O}_{3} \cdot 5 \mathrm{Nb}_{2} \mathrm{O}_{5}$ which 
has a maximum temperature of stability, decomposing at $1095{ }^{\circ} \mathrm{C}$ to $4 \mathrm{Bi}_{2} \mathrm{O}_{3} \cdot 9 \mathrm{Nb}_{2} \mathrm{O}_{5}$ plus $\mathrm{Bi}_{2} \mathrm{O}_{3} \cdot 6 \mathrm{Nb}_{2} \mathrm{O}_{5}$; and $\mathrm{Bi}_{2} \mathrm{O}_{3} \cdot 6 \mathrm{Nb}_{2} \mathrm{O}_{5}$ which has a minimum temperature of stability at $1,002{ }^{\circ} \mathrm{C}$ and melts incongruently at $1,242{ }^{\circ} \mathrm{C}$ to $\mathrm{Nb}_{2} \mathrm{O}_{5}$ and a liquid containing about 76 mole percent $\mathrm{Nb}_{2} \mathrm{O}_{5}$. The only eutectic in the system occurs at $1,180{ }^{\circ} \mathrm{C}$ and about 64 mole percent $\mathrm{Nb}_{2} \mathrm{O}_{5}$.

$\mathrm{Nb}_{2} \mathrm{O}_{5}$ enters into solid solution in the hightemperature cubic form of $\mathrm{Bi}_{2} \mathrm{O}_{3}$, raising the melting point to about $1,055^{\circ} \mathrm{C}$ and lowering the monoclinic to cubic phase transition from about $730{ }^{\circ} \mathrm{C}$ to about $610{ }^{\circ} \mathrm{C}$. A morphotropic transition occurs in the solid solution at about 19.5 mole percent to a pseudocubic form, and further solid solution occurs from 19.5 mole percent to about 23.5 mole percent $\mathrm{Nb}_{2} \mathrm{O}_{5}$. The pseudocubic form of $\mathrm{Bi}_{2} \mathrm{O}_{3}$ solid solution is stable from room temperature to a maximum solidus temperature of $1,096{ }^{\circ} \mathrm{C}$. No solid solution was observed in $\mathrm{Nb}_{2} \mathrm{O}_{5}$ or in any of the five binary compounds in the system.

\section{References}

[1] K. Dihlström, Z. Anorg. Allgem. Chem. 239, 57-64 (1938).

[2] B. Aurivillius, Arkiv Kemi 3 [20] 153-161 (1951).

[3] H. S. Roberts, Phys. Rev. 23, 386-95 (1924).

[4] H. F. Stimson, J. Research NBS 65A (Phys. and Chem.) 139-145 (1961).

[5] W. Guertler, Z. Anorg. Chem. 37, 222 (1903).

[6] L. G. Sillén, Arkiv Kemi 12A [18] 1-15 (1937).

[7] W. C. Schumb and E. S. Rittner, J. Am. Chem. Soc. 65, 1055-1060 (1943).

[8] B. Aurivillius and L. G. Sillén, Nature 155 [3932] 305306 (1945).

[9] L. G. Sillén, Z. Krist. 103 [4] 274-290 (1941).

[10] H. E. Swanson, M. C. Morris, and E. H. Evans, NBS Mono. 25, Sec. 2 (to be published).

[11] R. S. Roth, J. Research NBS 62 [27] (1959) RP2925.

[12] C. S. Hurlbut, Jr., Am. Min. 42 [3, 4] 178-183 (1957).

13] R. S. Roth and J. L. Waring, J. Research NBS 65A (Phys. and Chem.) No. 4, 337-344 (1961).

[14] F. Galasso and L. Katz, Acta Cryst. 14 [6] 647-650 (1961).

[15] R. O. Burbank and H. T. Evans, Acta Cryst. 1330 (1948).

[16] F. Holtzberg, A. Reisman, M. Berry, and M. Berkenblit, J. Am. Chem. Soc. 79 2039-2043 (1957).

[17] M. W. Shafer and R. Roy, Z. Krist. 110 [3] 241-248 (1958)

[18] H. J. Goldschmidt, J. Inst. Metals 87, 235-239 (1958-59).

[19] A. Reisman and F. Holzberg, J. Am. Chem. Soc. 81, 3182-3184 (1959).

[20] E. M. Levin and C. L. MeDaniel, J. Am. Ceram. Soc. 45, No. 8, 355-360 (Aug. 1962).

[21] R. S. Roth, in "Rare Earth Research," Ed., E. V. Kleber, The Macmillan Co. (1961), pp. 88-95. 